\title{
Artvin Çoruh Üniversitesi Yerleşkelerine Gelen Şebeke Sularının Bazı Fiziksel ve Kimyasal Özelliklerinin Araştırılması
}

\author{
Kazım Onur DEMIRARSLAN*1, Serden BAȘAK² \\ ${ }^{1}$ Artvin Çoruh Üniversitesi, Mühendislik Fakültesi, Çevre Mühendisliği Bölümü, 08000, Artvin, Türkiye \\ ${ }^{2}$ Artvin Çoruh Üniversitesi, Sağlık Bilimleri Fakültesi, İş Sağlı̆̆ı ve Güvenliği Bölümü, 08000, Artvin, Türkiye
}

(Alınış / Received: 12.06.2019, Kabul / Accepted: 12.11.2019, Online Yayınlanma/ Published Online: 30.12.2019)

\section{Anahtar Kelimeler} Artvin Çoruh Üniversitesi, İçme suyu, Su kalite parametreleri, Şebeke suları
Özet: Dünyada yaşamın devamlılığını sağlayan maddelerin başında su gelmektedir. Yeryüzünde suyun yokluğu şuan için düşünülememekle birlikte insanoğlu elinde bulunan kaynakları kirletmek için neredeyse birbirleri ile yarıș halindedir. Her gün evlere, okullara, işyerlerine rahatlıkla ulaşabilen suların belli bir standardı ve kalitesi olmalıdır. Bu da içme suyu kalite standardı olarak adlandırılmakta ve suyun taşıması gereken özellikler Türkiye'de ve dünyada yönetmeliklerle belirlenmektedir. Yapılan bu çalışmada, Artvin Çoruh Üniversitesi yerleşkelerinden alınan (Şehir, Seyitler, Hopa, Arhavi, Borçka Acarlar, Yusufeli, Şavşat) şebeke sularının fiziksel ve kimyasal yönden içme suları standartlarına uygunluğu araştırılmış ve bulunan değerlerin halk sağlığı açısından potansiyel bir risk oluşturup oluşturmadığının belirlenmesi amaçlanmıştır. Su numuneleri ilkbahar, yaz, sonbahar ve kış olmak üzere dönemsel olarak alınmıştır. Alınan örneklerin bulanıklık, iletkenlik, pH, çözünmüș oksijen (ÇO), sıcaklık, toplam sertlik, klorür, $\mathrm{NO}_{3}-\mathrm{N}$ ve $\mathrm{NH}_{3}-\mathrm{N}$ tayinleri yapılmıştır. Sonuçlar genel olarak sınır değerler içinde olmasına rağmen $\mathrm{NO}_{3}$ değeri Şehir Yerleşkesi'nde limit değer olan 50 ppm'in üzerinde bulunmuştur. İnsan sağlığı açısından önemli olan bu parametrenin neden sınır değer üzerinde olabileceği de makalede tartışılmıştır.

\section{Investigation of Some Physical and Chemical Properties of Network Water from Campuses of Artvin Çoruh University}

Keywords

Artvin Çoruh University, Drinking water,

Water quality parameters, Grid water

\begin{abstract}
Water is one of the main substances that ensure the continuity of life in the world. The absence of water on the earth is unthinkable for now, but human beings are in a race with each other to pollute the resources they have. The water that can easily reach homes, schools and workplaces every day should have a certain standard and quality.This is referred to as drinking water quality standards and specifications required for water transport is determined by the regulations in the world and Turkey.In this study, it was aimed to determine whether the water obtained from Artvin Coruh University campuses (Șehir, Seyitler, Hopa, Arhavi, Borçka Acarlar, Yusufeli, Şavşat) according to physical and chemical aspects of drinking water standards and whether the values found constitute a potential risk for public health.Water samples were taken periodically as spring, summer, autumn and winter. Turbidity, conductivity, $\mathrm{pH}$, dissolved oxygen (DO), temperature, total hardness, chloride, $\mathrm{NO}_{3}-\mathrm{N}$ and $\mathrm{NH}_{3}-\mathrm{N}$ were analyzed in water samples. The results are generally within the limit values, but the $\mathrm{NO}_{3}$ value is above 50 ppm which is the limit value in the City Campus. This parameter is very important for human health. The reason why it exceeds the limit value is discussed in the article.
\end{abstract}

\section{1,Giriş}

Su tüm canlılar için gerekli ve vazgeçilemez olan, ikame edilemeyen en önemli doğal kaynaklardan biridir [1,2]. Tüm bu özelliklerine rağmen ne yazık ki sınırlı doğal kaynaklar içerisindedir [3]. Su kaynakları endüstri ve tarımsal faaliyetlerin artmasıyla beraber nüfusun ve kentleşmenin 
çoğalması sonucunda hem aşırı miktarda tüketilmiş hem de kirlenmiştir [4]. Yerkürenin 3/4'ü su ile kaplıdır ancak kullanmaya uygun tatlı su miktarı oldukça kısıtlıdır. Dünyadaki tatlı suyun toplam miktarı yaklaşık 35 milyon $\mathrm{km}^{3}$ (toplam suyun $\% 2,5^{\prime}$ i) olup bunun yaklaşık $105000 \mathrm{~km}^{3}(\% 0,3)$ gibi oldukça küçük bir miktarı insanoğlu ve diğer canlıların kullanımına hizmet edebilecek niteliktedir [5,6]. Hayati öneme sahip su, çevre kirliliği, küresel ısınma gibi sebeplerle gün geçtikçe kullanılamaz hale gelmektedir [7]. Dünyada ve Türkiye'de sanayileşme ve kentleşmeyle beraber mevcut sistemlerin duyarsız kalması sonucunda suyla ilgili olan sorunlar hızla artmıștır. Ayrıca nüfus artış oranındaki hız hem ekolojik dengeyi hem de su kaynaklarını tehdit edecek duruma gelmiştir [8]. Türkiye her ne kadar su açısından zengin bir ülke olarak düşünülse de fert bașına düşen su miktarı bakımından dünyadaki ortalamanın oldukça altında kalmaktadır [9]. Tüm bu olumsuz tablolar bir yana birakılırsa insanlar temel ihtiyaçlarını karşılamak için (içme, kişisel temizlik, banyo, yemek hazırlama) normalde günde 50 L suya ihtiyaç duymaktadır. Ancak daha iyi bir yaşam standardı için 274 L/kişi gün olması gerektiği hakkında tartışmalar da bilgiler de bulunmaktadır [10].

Kentsel su arzl, suların herhangi bir kaynaktan alınarak şehir şebekeleri vasıtasıyla tüketicilere ulaştırılması olarak tanımlanabilmektedir [11]. Gerek suyun kaynağına bağlı olarak gerekse sözü edilen sistemlerle tüketicilere ulaştırılırken suların fizikokimyasal ve bakteriyolojik özelliklerinde değişiklikler görülmektedir. Suyun insan sağlı̆̆ için en önemli çevresel unsurlardan biri olması nedeniyle su analizleri ile suların sağlığa uygun olup olmadığı kontrol edilmelidir. Doğal sularda çözünmüş maddeler, tuzlar, gaz bileşenler, kimyasal bileşikler, hastalık yapan veya yapmayan organizmalar bulunmaktadır [12]. Dünya nüfusuna bakıldığında her beş kişiden biri güvenli içme suyuna sahip değildir ve bu rakam kabul edilemez ölçüde büyüktür. Her yıl 3-4 milyon insanın su kaynaklı hastalıklardan yaşamını yitirdiği Dünya Sağlık Örgütü (DSÖ) raporlarında açıklanmaktadır [13]. Bu nedenle özellikle kentsel su kaynaklarının fizikokimyasal ve bakteriyolojik analizlerinin yapılması oldukça önemlidir. Her birey için "temiz içme suyuna ulaşım" temel bir konudur ve insan haklarının en önemli olgusudur. İçme suyu dar anlamıyla, herhangi bir kurum ya da kiși tarafından insan tüketimi, yiyecek veya içecek hazırlanması, bu hazırlık ve tüketim aşamasında kullanılan her tür malzemenin temizliğinde kullanılması amacıyla tedarik edilen su olarak tanımlanabilir [14].

Suların fiziksel ve kimyasal yönden incelenmesinde genellikle bulanıklık, sıcaklık, pH değeri, toplam ve karbonat sertliği, çözünmüș oksijen miktarı, orto ve toplam fosfat, amonyum, nitrit, nitrat ve amonyak azotu, klor, iletkenlik gibi parametreler ele alınmaktadır [15].

Bu çalışmada, Artvin Çoruh Üniversitesi (AÇÜ) yerleşkelerinden (Şehir, Seyitler, Hopa, Arhavi, Borçka Acarlar, Yusufeli, Şavşat) alınmış olan şebeke sularının fiziksel ve kimyasal yönden İçme Suları Standartlarına uygunluğunu araştırmak ve halk sağlığı açısından potansiyel bir risk oluşturup oluşturmadığının belirlenmesi amaçlanmıştır. İlgili standartlar Tablo 1 de verilmektedir.

Su numuneleri ilkbahar, yaz, sonbahar ve kış olmak üzere dört farklı dönemde alınmıştır. Alınan örneklerin bulanıklık, iletkenlik, pH, ÇO, sıcaklık, toplam sertlik, klorür, $\mathrm{NO}_{3}-\mathrm{N}$ veNH $\mathrm{H}_{3}-\mathrm{N}$ tayinleri yapılmıştır. Elde edilen sonuçlar TS 266 İçme Suyu Kalite Parametre Değerleri [16], Avrupa Birliği (AB)İnsani Tüketim Amaçlı İstenilen Su Kalitesi Yönetmeliği (98/83/EC, on the quality of water intended for human consumption) [17] ve DSÖ [18] değerleri ile İnsani Tüketim Amaçlı Sular Hakkında Yönetmelikte [19] verilen sınır değerleri ile karşılaştırılmıştır.

\section{2, Materyal ve Metot}

Calıșma alanı Türkiye'nin Karadeniz Bölgesinin kuzeydoğusunda yer almaktadır. Alanın doğusunda Gürcistan, güneyinde Ardahan ve Erzurum, batısında Rize ve Erzurum illeri ile kuzeyinde Karadeniz bulunmaktadır [20]. Artvin ili 8 ilçe ve 310 köyden oluşmaktadır. İl deniz seviyesi ile 3937 m yükselti arasında yer almakta olup $7436 \mathrm{~km}^{2}$ lik yüzey alana sahiptir [21].

Tablo1.Çalışmada analizi yapılan parametreler için farklı standartların karşılaştırılması.

\begin{tabular}{|c|c|c|c|c|c|c|}
\hline \multicolumn{2}{|c|}{$\begin{array}{c}\text { Fiziko-Kimyasal } \\
\text { Parametreler } \\
\text { Birim } \\
\end{array}$} & \multicolumn{2}{|c|}{ 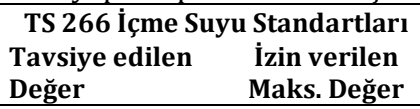 } & \multirow{2}{*}{$\begin{array}{c}\text { İnsani Tüketim Amaçlı } \\
\text { Sular Hakkında } \\
\text { Yönetmelik } \\
*\end{array}$} & \multirow{2}{*}{$\begin{array}{c}\text { AB İnsani Tüketim Amaçlı } \\
\text { İstenilen Su Kalitesi } \\
\text { Yönetmeliği }\end{array}$} & \multirow{2}{*}{$\begin{array}{c}\text { DSÖ } \\
\begin{array}{c}\text { İçme Suyu Kalite } \\
\text { Rehberi }\end{array} \\
*\end{array}$} \\
\hline Sicaklık & ${ }^{\circ} \mathrm{C}$ & 12 & 25 & & & \\
\hline pH & & $6,5-8,5$ & $6,5-9,2$ & $6,5-9,5$ & 6,5-9,5 & $6,5-9,5$ \\
\hline Bulanıklık & NTU & 5 & 25 & $\begin{array}{l}\text { Tüketicilerce kabul } \\
\text { edilebilir ve herhangi bir } \\
\text { anormal değişim yok }\end{array}$ & $\begin{array}{c}\text { Tüketicilerce kabul edilebilir } \\
\text { ve herhangi bir anormal } \\
\text { değişim yok }\end{array}$ & $<5$ \\
\hline İletkenlik & $\mu \mathrm{s} / \mathrm{cm}$ & 400 & 2000 & 2500 & 2500 & 2500 \\
\hline Klorür & $\mathrm{mg} / \mathrm{l}$ & 25 & 600 & 250 & 250 & 250 \\
\hline Sertlik & $\mathrm{mg} / \mathrm{l}$ & & 50 & $*$ & $*$ & $*$ \\
\hline Nitrat & $\mathrm{mg} / \mathrm{l}$ & 25 & 50 & 50 & 50 & 50 \\
\hline Amonyum & $\mathrm{mg} / \mathrm{l}$ & 0,05 & 0,5 & 0,5 & 0,5 & $*$ \\
\hline
\end{tabular}

*Yönetmelikte parametre değerleri belirtilmemiștir. 
Türkiye İstatistik Kurumu 2018 yılı Adrese Dayalı Nüfus Kayıt Sistemi sonuçlarına göre ilde 174010 kişinin yaşadığı belirtilmiştir [23].

Yapılan bu çalışmada AÇÜ’ ye ait yerleşkelerden su numuneleri alınarak fizikokimyasal bakımdan incelemeleri yapılmıștır. AÇÜ Şehir Yerleșkesi, Seyitler Yerleşkesi, Borçka Acarlar, Hopa, Şavşat, Arhavi, Yusufeli olmak üzere yedi yerleșkeden oluşmaktadır. Su numunelerinin alındığı noktalar Șekil 1'de verilmektedir. Çalıșma alanında bulunan 7 yerleșkeden ilkbahar, yaz, sonbahar ve kıș aylarında olmak üzere bir yılda dört adet su numunesi alınmıştır. Bu numunelerden bulanıklık, iletkenlik, pH, ÇO, sıcaklık, toplam sertlik, klorür, $\mathrm{NO}_{3}-\mathrm{N}$ ve $\mathrm{NH}_{3}-\mathrm{N}$ tayinleri yapılmıştır. Bulanıklık ölçümü için WTW TURB 550 cihazı, diğer ölçümler için ise $\mathrm{HACH}$ Multimeter HQ40d ve uygun problar (iletkenlik CDC40101 probu, pH PHC20101 probu, ÇO ve sıcaklık LD010101 probu,) kullanılmıştır. Toplam sertlik ve klorür tayinleri ise hazır test kitleri (Norateks) kullanılarak yapılmıştır. Tüm parametreler için ilgili ölçüm standartları takip edilmiştir.

Çalışmadaki $\mathrm{NO}_{3}-\mathrm{N}$ ölçümleri ISENO3181 probu kullanılarak gerçekleștirilmiștir. Yapılan analizler sonucunda elde edilen $\mathrm{NO}_{3}-\mathrm{N}$ değerleri Denklem 1 yardımıyla $\mathrm{NO}_{3}$ değerine dönüştürülmüştür [22].

$$
\mathrm{NO}_{3}\left(\frac{m g}{L}\right)=\mathrm{NO}_{3}-\mathrm{N}\left(\frac{m g}{L}\right) \times 4,42664
$$

Su numuneleri Ağustos 2017-Mayıs 2018 tarihleri arasında alınmıștır. Sular alınmadan önce musluklar ikişer dakika açık bırakılarak borularda bulunan suyun akması sağlanmıştır. ÇO ve sıcaklık ölçümleri, numune alım noktalarında derhal ölçülmüștür. Numuneler AÇÜ Çevre Mühendisliği Bölümü'ne uygun şartlarda nakledilmiştir. Diğer analizler, bölümde bulunan laboratuvarda suların özelliklerini kaybetmemesine dikkat edilerek ivedilikle gerçekleştirilmiştir.

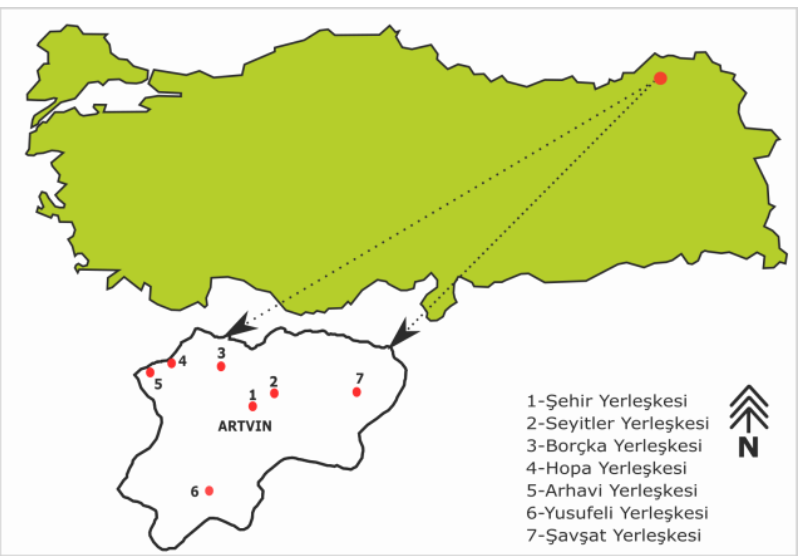

Şekil 1. Su numunelerinin alındığı AÇÜ yerleşkeleri

\section{Bulgular}

\subsection{Bulanıklık analizleri}

Mevsimlere göre elde edilen bulanıklık sonuçları Şekil 2'de verilmiştir. Bulanıklık değerleri Şehir yerleşkesi için tüm mevsimlerde TS266 Tavsiye Edilen sınır değerini (5 NTU) aşmamaktadır. AB sınır değeri olan 4 NTU ile DSÖ sınır değeri olan 5 NTU'yu da aşmayan örneklerde en yüksek değerin kış aylarında olduğu belirlenmiștir. En düşük değer ise ilkbahar aylarında ölçülmüştür. Sonbahar ve yaz aylarının değerleri birbirine yakın olduğu Şekil 2'de görülebilmektedir. Seyitler yerleşkesinin bulanıklı sonuçlarında özellikle yaz aylarında seviyenin oldukça yükseldiği görülebilmektedir. Bu değerin $\mathrm{AB}$ limit değerini aștığı ancak diğer limit değerler içerisinde kaldığı belirlenmiştir. En düşük değer ise sonbahar aylarında ölçülmüştür. Kış aylarında 2,56 NTU olan değer ilkbahar aylarında 0,55 NTU olarak bulunmuş ve tüm limit değerler çerçevesinde olduğu belirlenmiştir. Borçka Acarlar yerleşkesinde bulunan değerler ise özellikle kış ve sonbahar aylarında yüksektir. İlkbahar aylarında bulanıklı̆̆ın düștügü görülmekte ve en düșük seviyenin yaz aylarında olduğu anlaşılmaktadır. Sonuç olarak Borçka yerleşkesindeki şebeke suyunda tüm mevsimlerde bulanıklık değerinin sınır değerlerin altında olduğu görülmüștür. Arhavi yerleșkesinde ise bulanıklık oranı sonbahar mevsiminde en yüksek çıkmıștır. Limit değerlere bakıldı̆̆ında sonbaharda $\mathrm{AB}$ limit değerlerinin aşıldığı da belirlenmiştir. İkinci en yüksek değer ise kış mevsiminde görülmüștür. İlkbahar ve yaz aylarında ise en düşük seviye bulunmuştur. Şekil 2' de görülen mevsimlere göre bulanıklık sonuç grafiğinde Hopa yerleşkesi şebeke suyunda en yüksek değer sonbaharda ikinci olarak da yaz mevsiminde bulunmuştur. İlkbaharda 1,02 NTU değeri ölçülmüşken kış mevsiminde ise 0,71 NTU değeri elde edilmiştir. Tüm bu analiz değerlerinin sınır değerler içerisinde kaldığı belirlenmiştir. Şavşat yerleşkesinden alınan numunelerde sonuçların oldukça düşük olduğu görülebilmektedir. Sonuçlar kendi aralarında karşılaștırıldıklarında ilkbahar mevsiminde en yüksek değer, daha sonra sırasıyla yaz, sonbahar ve kış olarak seyretmektedir. Yusufeli yerleşkesi şehir sularının bulanıklık sonuçlarına bakıldığında ise tüm mevsimlerde sınır değerlerin altında olduğu anlaşılmaktadır (Şekil 2). Sonuçlar mevsimlere göre değerlendirildiğinde en yüksek değer sonbahar mevsiminde görülmüștür. Kış ve ilkbahar mevsimlerinde düşen bulanıklık sonuçları yaz aylarında en düşük değerine ulaşmaktadır. Mevsimsel analizlerden ylllk ortalamalara geçildiğinde bulanıklık parametresi için yerleşkeler Arhavi $>$ Seyitler $>$ Hopa > Borçka Acarlar > Şehir > Yusufeli > Şavşat șeklinde sıralanabilir. 


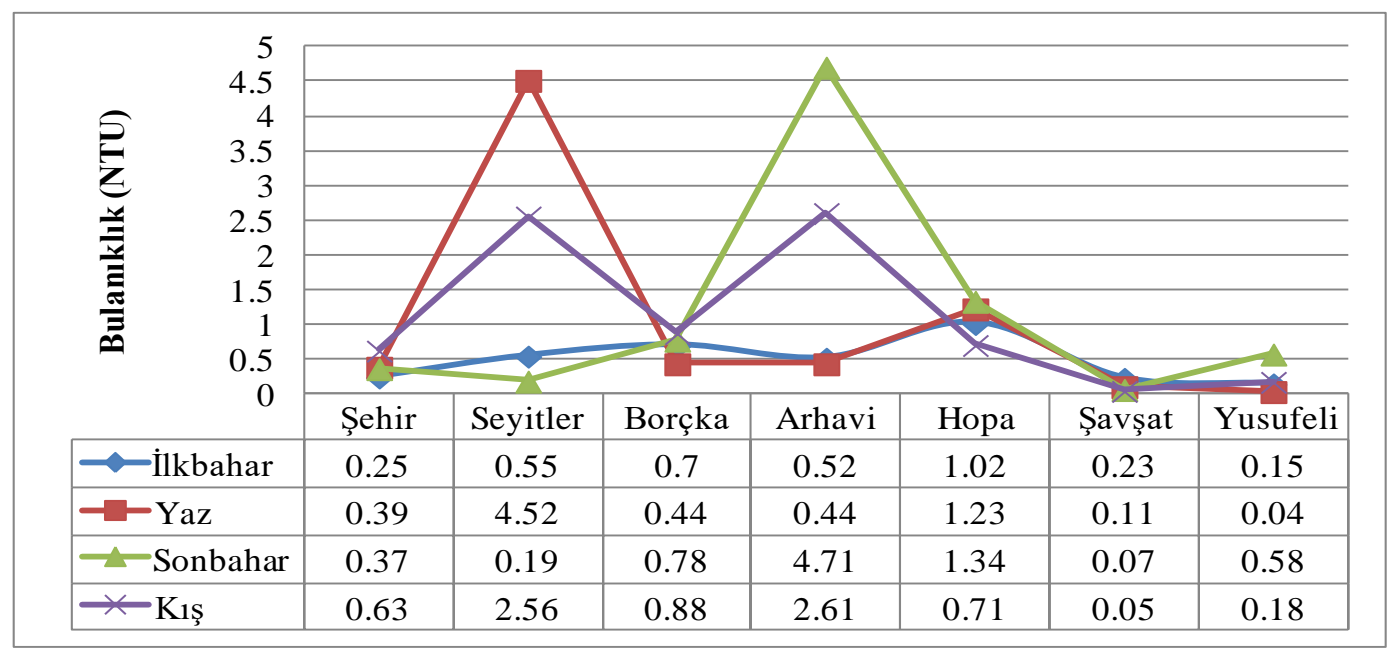

Şekil 2.Çalışma alanı mevsimlere göre bulanıklık analiz sonuçları

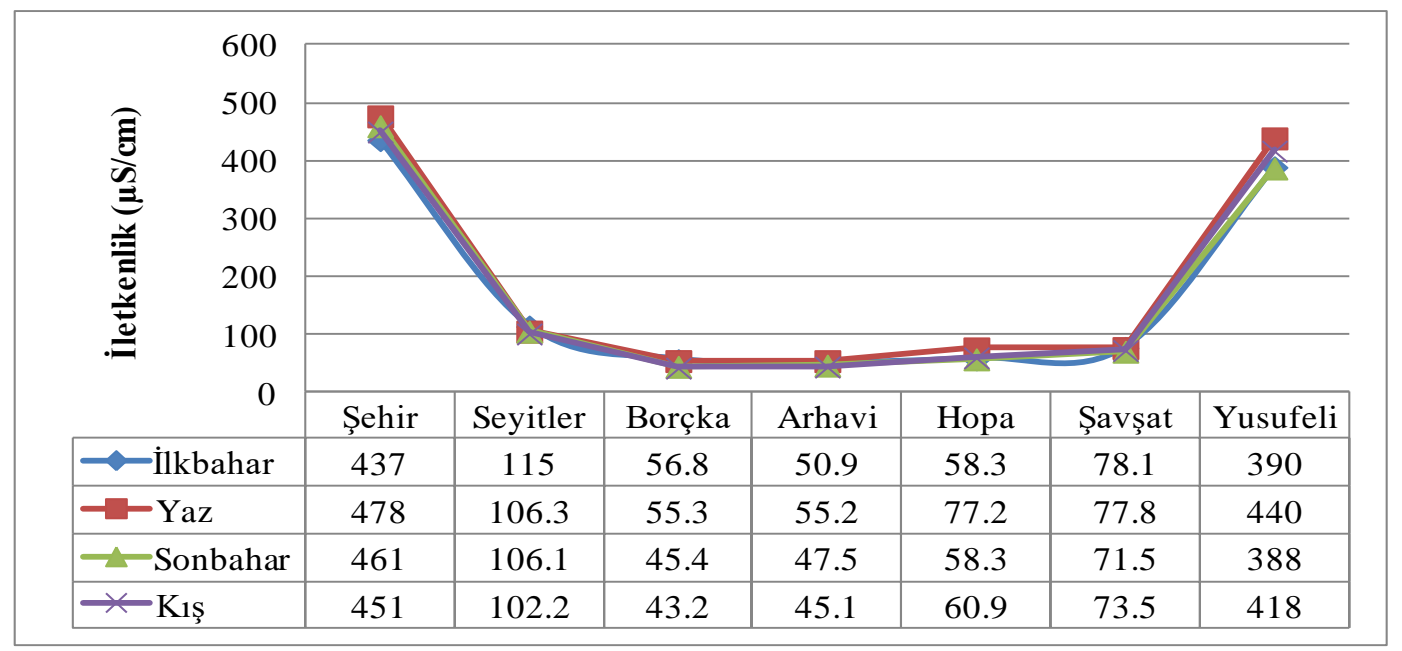

Şekil 3. Çalışma alanı mevsimlere göre iletkenlik analiz sonuçları.

\section{2 İletkenlik analizleri}

Mevsimlere göre elde edilen sonuçlar Şekil 3'te verilmektedir. Şekil 3'teki iletkenlik ölçüm sonuçları incelendiğinde Şehir yerleşkesinde yaz mevsiminde en yüksek değer elde edilmiştir. Sonbahar mevsiminde değer $461 \mu \mathrm{S} / \mathrm{cm}$ kıș ve ilkbahar aylarında ise sırasıyla 451 $\mu \mathrm{S} / \mathrm{cm}$ ve $437 \mu \mathrm{S} / \mathrm{cm}$ olarak ölçülmüştür. Şehir yerleşkesinden alınan numunelerin mevsimlere göre değerleri TS266, AB ve DSÖ iletkenlik parametresi olan $2500 \mu \mathrm{S} / \mathrm{cm}$ sınır değerini aşmamaktadır. Seyitler yerleşkesi numunelerinin ölçümlerinde ilkbahar mevsiminde en yüksek değer görülmüştür. Sonbahar ve yaz aylarında değerler yaklașık olarak aynı olup sırasıyla $106,1 \mu \mathrm{S} / \mathrm{cm}$ ve 106,3 $\mu \mathrm{S} / \mathrm{cm}^{\prime}$ dir. Ölçülen sonuçların sınır değerlerini aşmadığı anlaşılmıştır. Borçka Acarlar yerleşkesi șehir şebekesinden alınan numunelerde değerin en fazla olduğu mevsim ilkbahardır. Sonbahar ve yaz aylarında değerlerler sırasıyla $45,4 \mu \mathrm{S} / \mathrm{cm}$ ve 55,3 $\mu \mathrm{S} / \mathrm{cm}$ 'dir. Yine elde edilen sonuçların sınır değerlerini aşmadığı görülebilmektedir. Arhavi yerleşkesinde değerlerin en yüksek olduğu mevsim yaz olmuștur. İlkbahar aylarında ikinci en yüksek değerinde olan iletkenlik en düşük değerini ise kış aylarında ölçülmüştür. Tüm mevsimlerin değerleri incelendiğinde ise hiçbir sınır değerin aşılmadı̆̆ görülmektedir. Hopa yerleşkesinin şebeke sularında en yüksek değer yaz mevsiminde bulunmuș sonbahar ve ilkbahar aylarında yakın değerler çıkmıştır. Kış mevsiminde ise ikinci en yüksek değer ölçülmüștür. Tüm değerler karșılaștırılan sınır değerlerin oldukça altında olduğu belirlenmiştir. Şavşat yerleşkesi şebeke suyu numunelerinde ilkbahar ve yaz mevsimlerinde yüksek değerler bulunmuş, kış ve sonbahar mevsimlerinde ise bu değerlerin düştüğü görülmüștür. Tüm mevsimlerde bulunan sonuçların yönetmeliklerdeki sınır değerlerden düşük olduğu belirlenmiștir. Yusufeli yerleșkesinde tüm mevsimlerde alınan su numunelerinde yönetmeliklerdeki sınır değerlerinin aşmadı̆̆ anlaşılmış ve kendi aralarındakarșılaștırıldıklarında en yüksek değerin yaz mevsiminde olduğu görülmüștür.

Kıș mevsiminde ikinci en yüksek değer gözlemlenmiștir. Sonbahar ve ilkbahar mevsimlerinde ise yaklaşlk benzer değerler ölçülmüştür.

İletkenlik analizi sonuçlarının yıllık ortalamaları karşılaştırıldığında Şehir > Yusufeli > Seyitler > Şavşat > Hopa > Borçka Acarlar > Arhavi sıralaması meydana gelmektedir.

\section{$3.3 \mathrm{pH}$ analizleri}

Analizlerde elde edilen pH değerleri Şekil 4'de gösterilmektedir. Şehir yerleşkesi ş̧ebeke suyu pH ölçümlerine bakıldığında (Şekil 4) ilkbahar ve sonbahar mevsimlerinde değerlerin aynı olduğu görülmektedir. Yaz mevsiminde 7,65 olan pH değeri kış aylarında 7,56 olarak 
belirlenmiștir. Bu değerler TS 266 ve İTASHY'de bulunan 6,5-9,5 sınırlarını așmamaktadır. Ayrıca AB sınırı olan yine 6,5-9,5 değeri ile DSÖ sınırı olan 6,5-8,5 değerini aşmadığı görülmektedir. Ancak ilkbahar ve sonbahar aylarında DSÖ sınır değeri olan 8,5’a yaklaștığı belirlenmiştir. Seyitler yerleşkesi şebeke sularında $\mathrm{pH}$ değerlerinin tüm mevsimlerde 8,15-8,75 arasında olduğu bulunmuştur. $\mathrm{Bu}$ değerler incelendiğinde tüm mevsimlerde TS 266, İTASHY ve AB limit değerler arasında kaldığı ancak ilkbahar ve sonbahar aylarında DSÖ sınır değerlerini aştı̆̆ belirlenmiştir. Borçka Acarlar yerleșkesi șebeke suyunda sonbahar ve yaz aylarında pH'ın yükseldiği, ilkbahar ve kış aylarında düştüğü bulunmuștur. Arhavi yerleșkesinde kış aylarında pH artmakta, sonbahar ve ilkbahar aylarında ise yaklaşık olarak eşit değerlerde olduğu görülebilmektedir. En düşük seviye ise yaz aylarında ölçülmüştür. Hopa yerleşkesi şebeke sularının pH değerleri sonbahar mevsiminde yükselmekte ilkbahar ve kış mevsimlerinde düșmekte ve en düșük değerin yaz mevsiminde olduğu anlaşılmaktadır. Tüm mevsimlere bakıldığında yönetmeliklerdeki sınır değerlerin altında oldukları bulunmuștur. Şavşat yerleşkesi analizlerinde 8,21-8,47 arasında değerler elde edilmiştir. Yusufeli yerleșkesi şebeke suyu pH ölçümleri ise sınır değerlerle karşılaştırıldığında uygun olduğu görülebilmektedir. Mevsimler kendi aralarında karşılaștırıldıklarında ise en yüksek değer sonbahar mevsiminde bulunmuştur. İkinci en yüksek değer kış mevsiminde görülmüş, yaz ve ilkbahar mevsimlerinde düşük sonuçlar ölçülmüștür.Şebeke sularındaki pH oranları yıllık ortalamalar bazında Seyitler $>$ Şavşat $>$ Arhavi $>$ Yusufeli > Hopa > Borçka Acarlar> Şehir olarakbulunmuştur.

\section{4 Çözünmüș Oksijen analizleri}

Elde edilen ÇO verileri Şekil 5'te görülebilmektedir. Şekil 5 incelendiğinde Şehir yerleşkesi şebeke suyu ÇO değerinin en yüksek olduğu mevsim kış olarak görülmektedir. En düşük seviye ilkbahar aylarında gözlenirken yaz ve sonbahar aylarında sırasıyla 8,23 $\mathrm{mg} / \mathrm{L}, 8,05 \mathrm{mg} / \mathrm{L}$ olarak ölçülmüştür. Seyitler yerleşkesi ÇO değerlerinin en yüksek olduğu mevsim yine kış aylarıdır. En düșük seviye yaz aylarında gözlenirken ilkbahar ve sonbahar aylarında ise sırasıyla 9,02 mg/L, 9,07 mg/L olarak ölçülmüștür. Borçka Acarlar yerleşkesindeki en yüksek ÇO değeri kış aylarında ölçülmüș, en düșük değerse yaz aylarında görülmüștür. Sonbahar aylarında 9,32 mg/L, ilkbahar aylarında ise 8,76 $\mathrm{mg} / \mathrm{L}$ ölçülmüștür. Arhavi yerleşkesinde diğer yerleşkelerde olduğu gibi en yüksek değer kış en düșük değer yaz aylarında ölçülmüştür. Hopa yerleşkesinde diğer yerleşkelerden farklı olarak ÇO miktarının sonbahar aylarında daha fazla olduğu görülebilmektedir. İlkbahar mevsiminde $7,79 \mathrm{mg} / \mathrm{L}$ olan ÇO seviyesi kış mevsiminde $7,48 \mathrm{mg} / \mathrm{L}$ yaz mevsiminde ise $7,23 \mathrm{mg} / \mathrm{L}$ olarak ölçülmüştür. Şavşat yerleşkesinde kış mevsiminde en yüksek değer ölçülürken en düşük değer yaz mevsiminde belirlenmiștir. Yusufeli şebeke suyunun ÇO miktarı kıș ve sonbahar aylarında yüksek iken en düşük miktar ilkbahar aylarında belirlenmiştir.

Mevsimsel yapılan analiz sonuçlarının yıllık ortalamaları alındığında ÇO için sıralama Borçka Acarlar > Arhavi > Şavşat $>$ Seyitler $>$ Şehir $>$ Hopa $>$ Yusufeli, yıllık sıcaklık ortalamaları için Arhavi > Borçka Acarlar > Şehir > Hopa > Yusufeli $>$ Seyitler $>$ Şavşat sıralaması elde edilmiștir.

\subsection{Sicaklık ölçümleri}

Yerleşkelerde yapılan sıcaklık ölçümlerinin sonuçları Şekil 6'da verilmektedir. Normal olarak en düşük sıcaklık değeri kış ayında en yüksek değer ise yaz ayında ölçülmüștür. İlkbahar ve sonbahar aylarında ise sırasıyla $21,7{ }^{\circ} \mathrm{C}$ ile $20,3{ }^{\circ} \mathrm{C}$ değerleri bulunmuștur. Seyitler yerleșkesi șebeke sularında da en düşük sıcaklık değeri kış ayında en yüksek değer ise yaz ayında ölçülmüştür. İlkbahar ve sonbahar aylarında ise sırasıyla $16,2{ }^{\circ} \mathrm{C}$ ile $18,3{ }^{\circ} \mathrm{C}$ değerleri bulunmuştur.

Şekil 6' daki Borçka Acarlar yerleşkesi şebeke suyu sıcaklıkları incelendiğinde, ilkbahar ve yaz aylarında yüksek olan su sıcaklığının sonbahar aylarında düşmeye başladığı ve kış aylarında ise en düşük seviyeye geldiği görülebilmektedir. Arhavi yerleşkesinde ise şebeke suyu sıcaklık değerinin en düşük ölçüldüğü mevsim kış aylarıdır $\left(13,7^{\circ} \mathrm{C}\right)$. En yüksek değer ise yaz aylarında $\left(25,2{ }^{\circ} \mathrm{C}\right)$ bulunmuştur. İkinci en yüksek değer ilkbahar aylarındadır $\left(22,5^{\circ} \mathrm{C}\right)$ ve ardından sonbahar ayları $\left(19,1^{\circ} \mathrm{C}\right)$ gelmektedir.

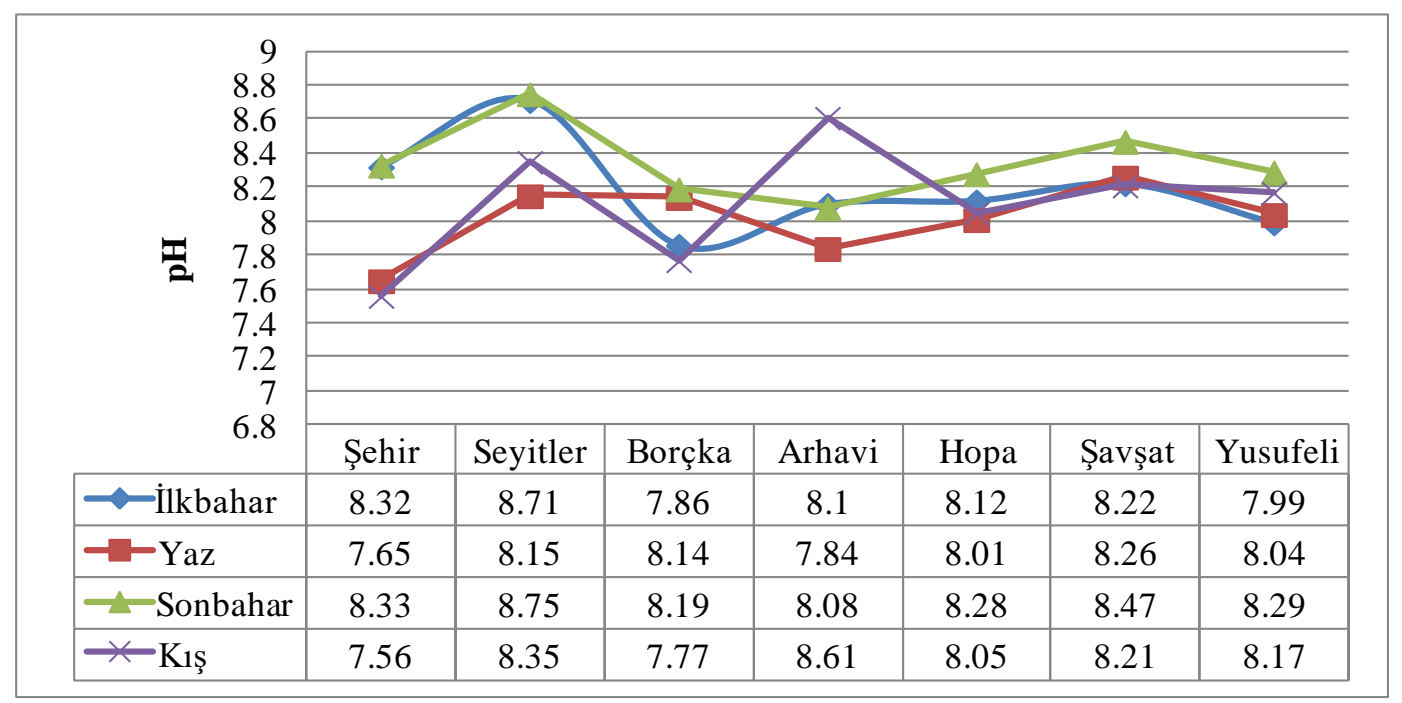

Şekil 4. Çalışma alanı mevsimlere göre $\mathrm{pH}$ analiz sonuçları 


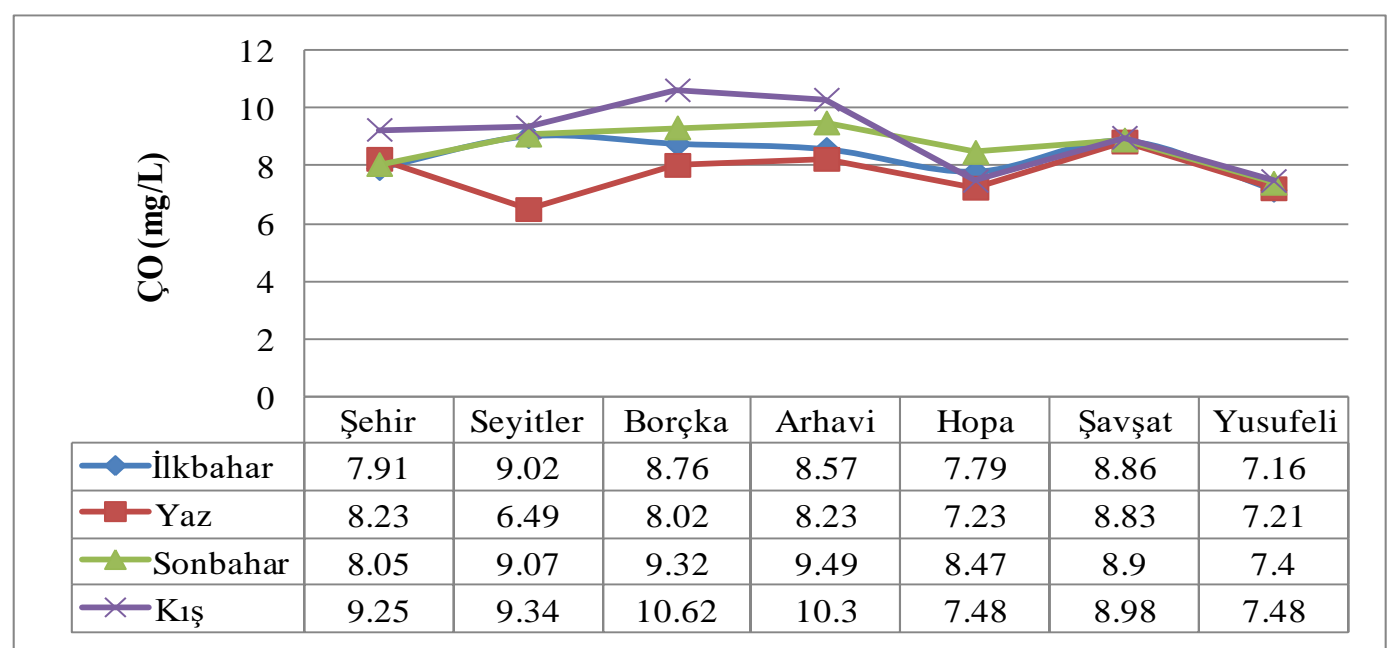

Şekil 5.Çalışma alanı mevsimlere göre ÇO analiz sonuçları

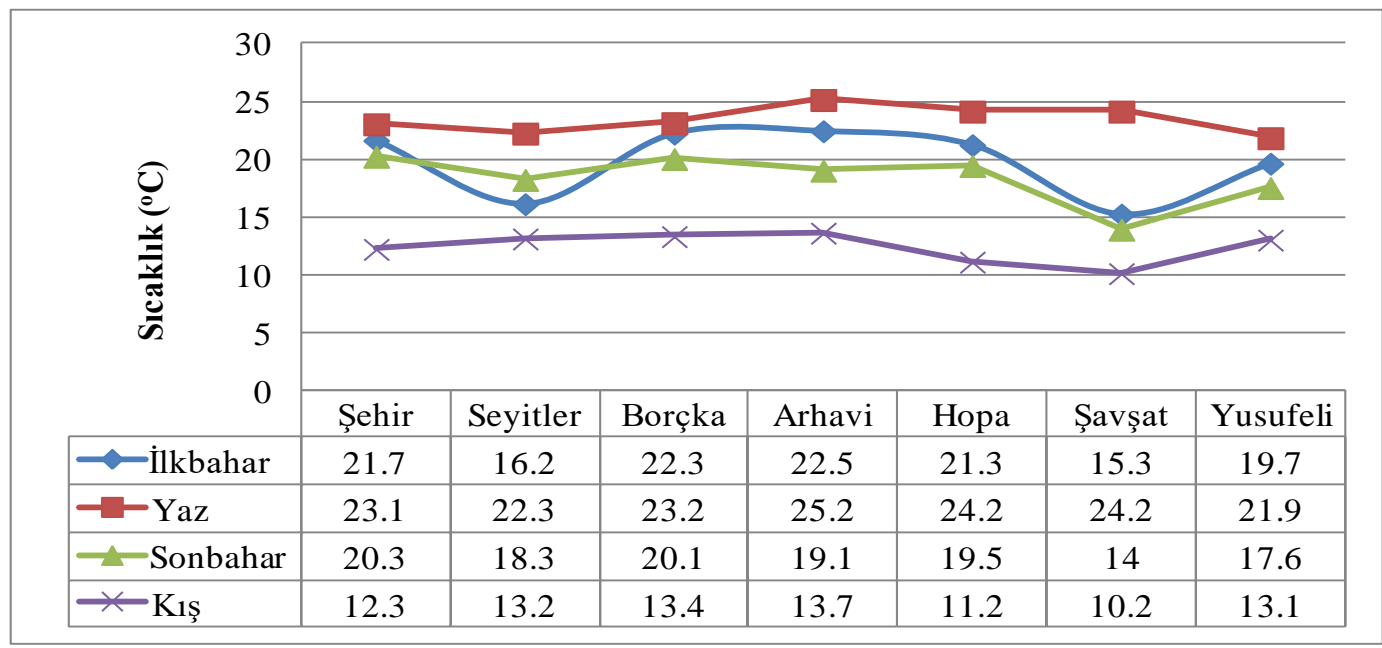

Şekil 6.Çalışma alanı mevsimlere göre sıcaklık ölçüm sonuçları

Hopa yerleşkesinde sıcaklık yaz aylarında yüksek olmakla birlikte $\left(24,2^{\circ} \mathrm{C}\right)$, ilkbahar mevsiminde 21,3 ${ }^{\circ} \mathrm{C}$ ve sonbahar mevsiminde $19,5{ }^{\circ} \mathrm{C}$ olarak ölçülmüştür. Kış mevsiminde ise sıcaklık en düşük değer olan 19,5 ㄷ bulunmuştur. Şavşat yerleşkesinde yine diğer yerleşkelerde olduğu üzere en yüksek sıcaklık yaz mevsiminde ölçülmüş olup sıcaklık değerlerinde sırasıyla ilkbahar, sonbahar ve kış mevsimlerine göre değişiklik görülmüştür. Yusufeli şebeke sularında ise sıcaklık değerleri sırasıyla ilkbahar, yaz, sonbahar ve kış olarak ölçülmüştür.

\subsection{Toplam sertlik tayinleri}

Deneylerde elde edilen mevsimlik sonuçlar Şekil 7'de gösterilmiştir. Şekil 7'deki sertlik analizi grafiği incelendiğinde Şehir yerleşkesi şebeke suları ilkbahar ve kış aylarında sert, yaz ve sonbahar aylarında ise çok sert özellikte olduğu söylenebilir. Seyitler yerleşkesinde ise suların sonbahar aylarında sert, kış, yaz ve ilkbahar aylarında ise yumuşak özellikte olduğu belirlenmiştir. Borçka Acarlar şebeke suyunun sertlik derecesinin her mevsimde sabit olduğu $\left(35,6 \mathrm{mg} \mathrm{CaCO}_{3} / \mathrm{L}\right)$ ve bu da suyun yumuşak su olduğunu göstermektedir. Arhavi yerleşkesi şebeke suyunun her mevsim yumuşak su olduğu belirlenmiştir. Hopa yerleşkesi sertlik ölçümlerinde ise her mevsimde $35,6 \mathrm{mg} \mathrm{CaCO} / \mathrm{L}$ değeri elde edilmiş ve suyun tüm mevsimlerde çok yumuşak olduğu belirlenmiştir. Şavşat yerleşkesi şebeke sularının tüm mevsimlerde yumuşak su özelliği taşıdığı Şekil 7'den anlaşılmaktadır. Mevsimler kendi aralarında karşılaştırıldıklarında ise sonbahar mevsiminde $\mathrm{CaCO}_{3}$ oranının 71,2 mg olduğu, yaz mevsiminde bu değerin 53,4 mg'a düștüğü belirlenmiștir.

Kış ve ilkbahar mevsimlerinde ise değerler 35,6 mg olarak birbirine eşit çıkmışlardır. Değerler incelendiğinde tüm mevsimlerde suyun sert nitelikte olduğu söylenebilir. Yusufeli yerleşkesinde mevsimler arasında karşılaştırma yapıldığında özellikle yaz mevsiminde $1 \mathrm{~L}$ su içerisinde bulunan $\mathrm{CaCO}_{3}$ miktarının 409,4 mg olduğu, kış ve ilkbahar mevsimlerinde bu miktarın $213,6 \mathrm{mg}$, yazın ise 231,4 mg olduğu analiz sonuçlarına göre bulunmuştur.

Yıllık ortalama sertlik değerlerinin Şehir > Yusufeli $>$ Seyitler > Şavşat $>$ Borçka Acarlar > Arhavi > Hopa olduğu görülmektedir. 


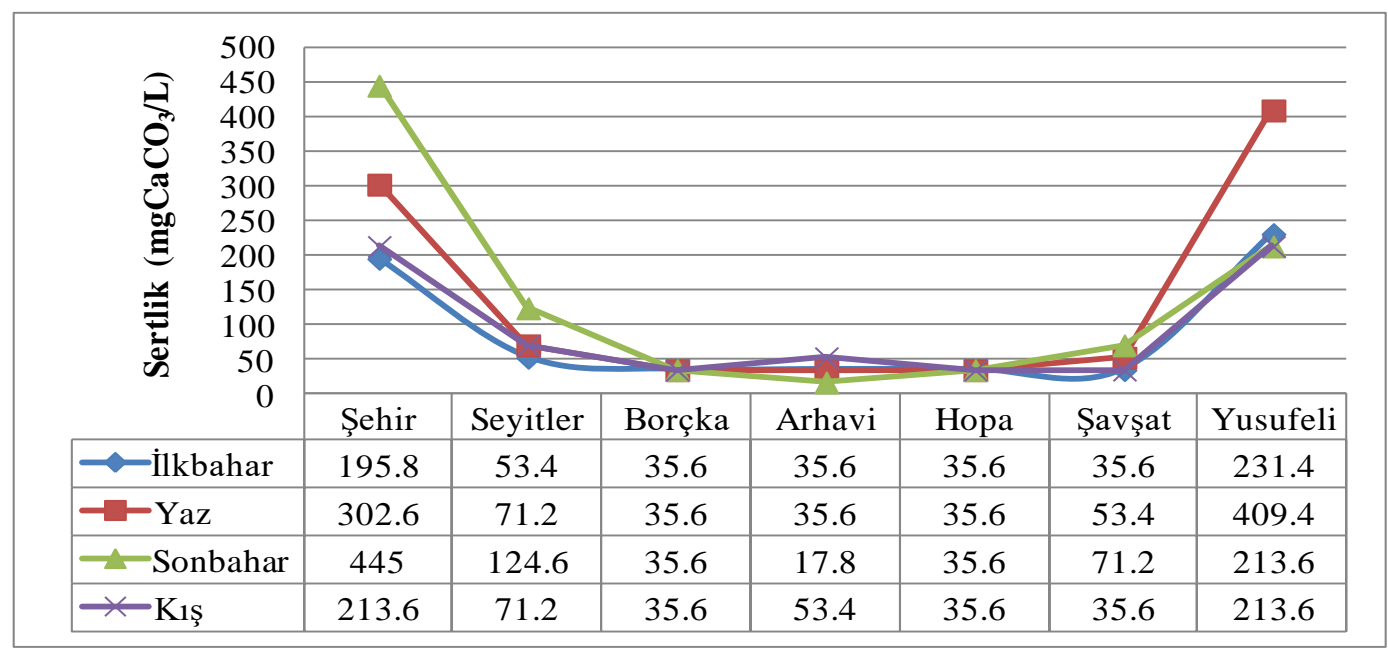

Şekil 7.Çalışma alanı mevsimlere göre sertlik tayin sonuçları.

\subsection{Klorür tayinleri}

Klorür sonuçları Şekil 8' deki grafikte verilmiștir. Şehir yerleşkeden alınan su numunelerinde en yüksek değer sonbahar aylarında 3 ppm olarak ölçülmüsstür. En düşük değer ise ilkbahar aylarında görülmüștür $(<0,03 \mathrm{ppm})$. Yaz aylarında $1 \mathrm{ppm}$ olan klor miktarı kış aylarında 0,1 ppm'e kadar düșebilmektedir. Seyitler yerleșkesinde klor değeri tüm mevsimlerde 0,03 ppm'den azdır. Borçka Acarlar yerleşkesinden alınan su numunelerinde klor miktarı tüm mevsimlerde 0,3 ppm'den az bulunmuştur. Arhavi yerleșkesinden alınan su numunelerindeki klor seviyelerine bakıldığında sonbahar aylarında $3 \mathrm{ppm}$ diğer mevsimlerde 0,3 ppm'den küçük olduğu belirlenmiştir. Hopa şebeke suyunda yapılan klor analizlerinde en yüksek değerin $0,5 \mathrm{ppm}$ ile sonbahar mevsiminde olduğu, yaz ve kış mevsiminde bu değerin 0,3 ppm'den düşük olduğu ve ilkbahar mevsiminde en düșük seviyede 0,05 ppm'den düşük olduğu bulunmuştur. Şavşat yerleşkesinden alınan numunelerde klor ölçümleri de yapılarak sonuçlar değerlendirilmiștir. Buna göre sonbahar mevsiminde 0,5 ppm olan klor değeri yaz mevsiminde $0,3 \mathrm{ppm}$ olmuştur. Kış mevsiminde 0,3 ppm çıkan klor seviyesi ise ilkbahar mevsiminde 0,03 ppm'e kadar düşmüştür. Yusufeli yerleșkesi şebeke suyu numunelerinde yapılan klor testinde ise en yüksek değerin $(0,3 \mathrm{ppm}) \mathrm{yaz}$, sonbahar ve kış mevsimlerinde olduğu görülmüştür. İlkbahar mevsiminde alınan numuneden elde edilen sonuç ise 0,03 ppm' dir.

Klor analizine göre Şehir $>$ Arhavi $>$ Hopa $>$ Şavşat $>$ Borçka Acarlar > Yusufeli > Seyitler sıralaması elde edilmektedir.

\section{8 $\mathrm{NO}_{3}$ Analizleri}

Elde edilen sonuçlardan Şekil 9'daki $\mathrm{NO}_{3}$ grafiği oluşturulmuştur. $\mathrm{Bu}$ veriler TS 266 değeri (50 $\mathrm{mg} / \mathrm{L}), A B$ ve DSÖ değerleri ( $50 \mathrm{mg} / \mathrm{L})$ ile İTASHY verilen sınır değerle $(50 \mathrm{mg} / \mathrm{L})$ karşılaștırılmıștır.
Şehir yerleşkesinin şebeke suyunda ilkbahar mevsiminde tüm sınır değerlerin aşıldı̆̆ görülebilmektedir. İkinci olarak en yüksek değerin ölçüldüğü mevsim ise kıştır. Ardından sonbahar gelmekte ve en düşük $\mathrm{NO}_{3}$ değerinin bulunduğu mevsimin ise yaz olduğu görülebilmektedir. İlkbahar, sonbahar ve kış ayları bölgede en çok yağışın görüldüğü mevsimlerdir. Seyitler yerleşkesi şebeke suyunda hiçbir mevsimde sınır değerlerin aşılmadığı görülebilmektedir. Ancak en yüksek değer ilkbahar aylarında bulunmuştur.

Diğer mevsimlerde alınan su numunelerindeki $\mathrm{NO}_{3}$ miktarlarına göre karşılaștırıldığında sırasıyla kıș, sonbahar ve yaz mevsimleri gelmektedir. Borçka Acarlar yerleşkesinde ise hiçbir mevsimde sınır değerlerin aşılmadığı görülebilmektedir. En yüksek değer ise yine ilkbahar aylarında ölçülmüştür. Diğer mevsimler karşılaştırıldığında kış, sonbahar ve yaz mevsimleri gelmektedir. Arhavi yerleșkesi șehir şebeke suyundaki en yüksek $\mathrm{NO}_{3}$ değerleri ilkbahar, kıș, sonbahar aylarında ölçülmüștür. Yaz aylarında ise en düşük değer bulunmuştur. Tüm değerler limitlerle karșılaştırılırsa oldukça altında oldukları söylenebilir. Hopa yerleşkesi şebeke sularının analiz sonuçları incelendiğinde ise mevsimlere göre farklılık görülse de bu değerlerin yönetmeliklerdeki sınır değerlerin bir hayli altında olduğu anlașlmaktadır. Şekil 9 'a göre Șavşat yerleșkesinde tüm mevsimlerde ölçülen $\mathrm{NO}_{3}$ değerlerinin yönetmeliklerdeki sınır değerlerin oldukça altında olduğu görülebilmektedir. Değerler mevsimler arasında karşılaştırıldığında en yüksek değer kış mevsiminde ölçülmüştür. Sonbahar ve yaz aylarında düşen $\mathrm{NO}_{3}$ değerinin en düşük miktarı ilkbahar mevsiminde belirlenmiștir. Şekil 9'daki analiz sonuçlarına göre Yusufeli yerleşkesi şebeke sularındaki $\mathrm{NO}_{3}$ miktarı tüm mevsimlerde sınır değerlerin altında kalmaktadır. Mevsimlere göre karşılaştırıldıklarında ilkbahar mevsiminde değerler oldukça yüksektir. İkinci en yüksek değer ise kış mevsiminde ölçülmüştür. Sonbahar ve yaz mevsimlerinde ise şebeke suyundaki $\mathrm{NO}_{3}$ miktarı düșüş göstermektedir. 


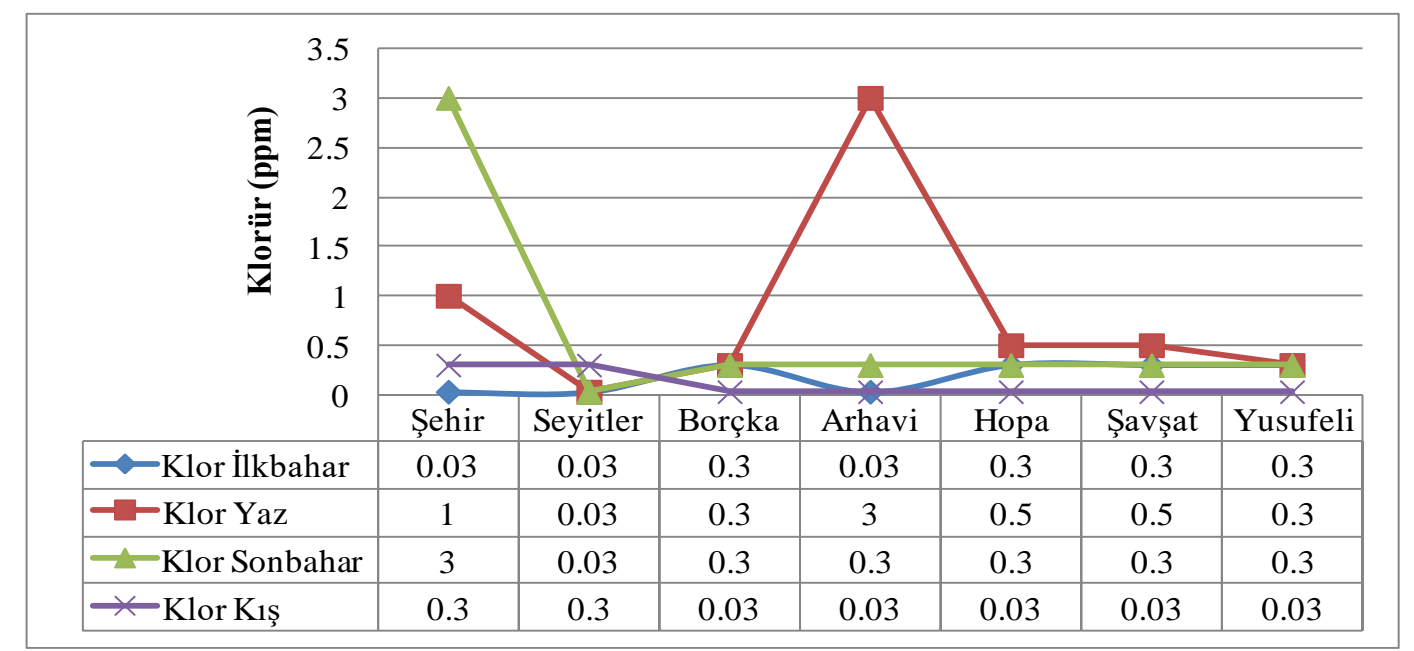

Şekil 8. Çalışma alanı mevsimlere göre klorür tayini sonuçları.

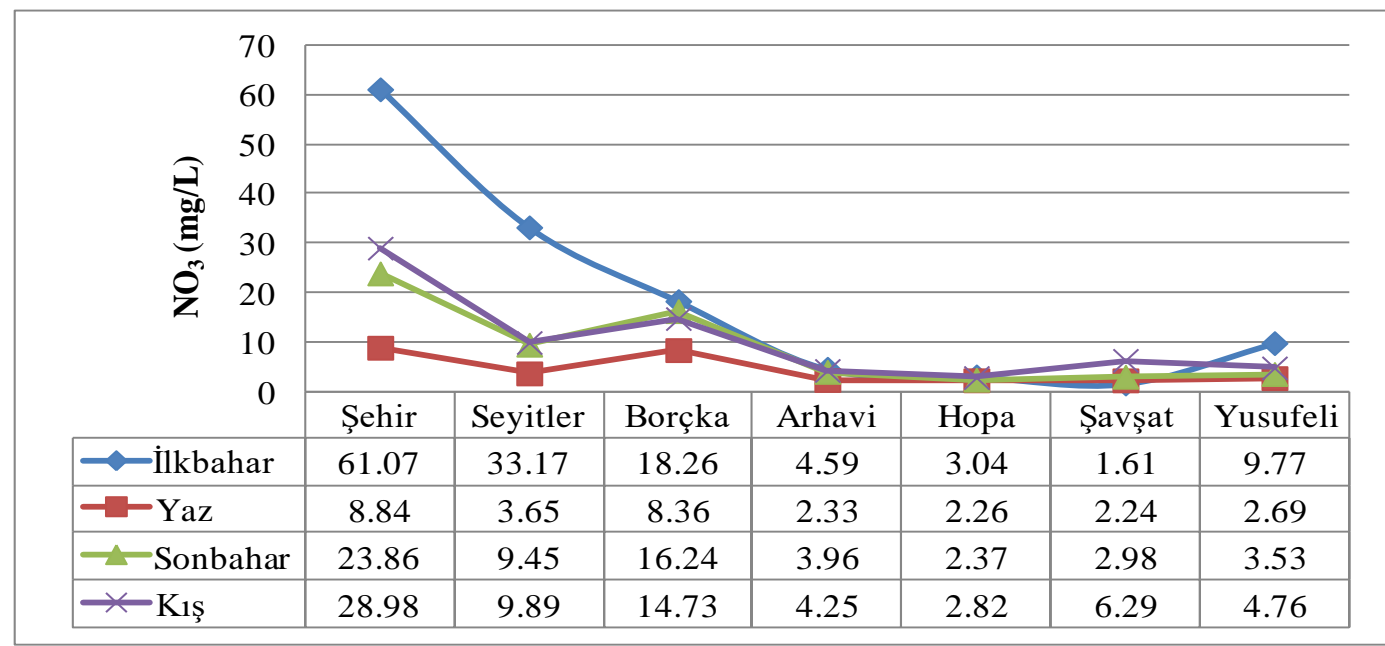

Şekil 9. Çalışma alanı mevsimlere göre $\mathrm{NO}_{3}$ tayini sonuçları

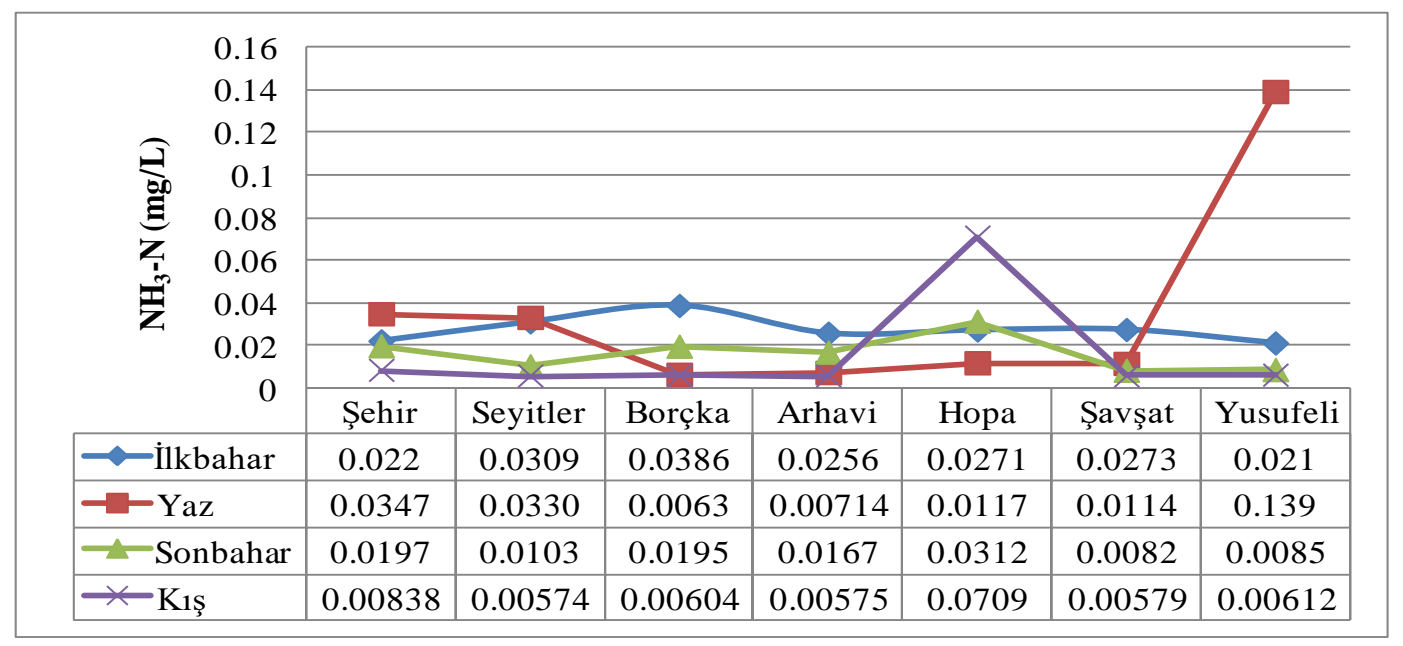

Şekil 10. Çalışma alanı mevsimlere göre $\mathrm{NH}_{3}-\mathrm{N}$ tayini sonuçları

Yerleşkelerin şebeke sularındaki $\mathrm{NO}_{3}$ miktarlarının yıllık ortalaması alındığında Şehir > Borçka Acarlar $>$ Seyitler > Yusufeli > Arhavi > Şavşat > Hopa sıralaması oluşmaktadır.

\section{9 $\mathrm{NH}_{3}-\mathrm{N}$ Analizleri}

Şebeke sularının $\mathrm{NH}_{3}-\mathrm{N}$ ölçümleri ise laboratuvar koşullarında ISENH318103 probu ile gerçekleştirilmiştir. Şehir yerleşkesi şebeke suyunun $\mathrm{NH}_{3}-\mathrm{N}$ ölçüm sonuçlarını gösteren Şekil 10 incelendiğinde amonyak azotunun yaz aylarında en yüksek seviyeye geldiği görülmektedir. İlkbahar ve sonbahar aylarında seviye yaklaşık olarak benzer iken en düşük değer ise kış aylarında görülmüştür. Seyitler yerleşkesinde amonyak azotunun yaz aylarında en yüksek seviyeye gelmektedir. Diğer en yüksek mevsim ise ilkbahar aylarıdır. Sonbahar 
aylarında değer $0,0103 \mathrm{mg} / \mathrm{L}$ olurken en düşük değer kış aylarında $0,00574 \mathrm{mg} / \mathrm{L}$ olarak ölçülmüştür. Borçka Acarlar analizleri incelendiğinde amonyak azotunun ilkbahar aylarında en yüksek seviyeye ulaştığı görülmüştür. Diğer en yüksek mevsim sonbahar aylarıdır. Kış ve yaz aylarında değerler birbirine yakın olup sırasıyla $0,00604 \mathrm{mg} / \mathrm{L}$ ile $0,0063 \mathrm{mg} / \mathrm{L}$ olarak bulunmuştur. Arhavi yerleşkesi $\mathrm{NH}_{3}-\mathrm{N}$ ölçüm sonuçları incelendiğinde ilkbahar aylarında en yüksek değere ulaștığı belirlenmiștir. Sonbahar aylarında 0,0167 $\mathrm{mg} / \mathrm{L}$ olan amonyak azotu değeri yaz ve kıș aylarında düşmekte ve sırasıyla $0,00714 \mathrm{mg} / \mathrm{L}$ ve $0,00575 \mathrm{mg} / \mathrm{L}$ olmaktadır. Hopa yerleşkesi için yapılan analizlerde kış mevsiminde amonyak azotunun yüksek çıkttğı belirlenmiștir. Ancak diğer mevsimlere bakılacak olursa sonbaharda 0,0312 $\mathrm{mg} / \mathrm{L}$, ilkbaharda $0,0271 \mathrm{mg} / \mathrm{L}$ ve yaz mevsiminde ise $0,0117 \mathrm{mg} / \mathrm{L}$ sonuçları bulunmuştur. Şavşat yerleşkesi analiz sonuçlarına göre mevsimler arasındaki değișimlere bakıldığında en yüksek değerin ilkbahar mevsiminde olduğu anlaşılmaktadır. Yaz mevsimi için alınan numune analizi sonucunda $0,0114 \mathrm{mg} / \mathrm{L}$ olan amonyak azotu miktarı sonbahar mevsiminde ise $0,0082 \mathrm{mg} / \mathrm{L}$ 'ye düşmüştür. En düşük değer ise kış mevsiminde 0,00579 $\mathrm{mg} / \mathrm{L}$ olarak bulunmuştur. Yusufeli yerleşkesi analiz sonuçlarında mevsimler arasındaki değişimlere bakıldığında en yüksek değerin yaz mevsiminde olduğu anlaşılmaktadır. İlkbahar mevsimi için alınan numune analizi sonucunda $0,021 \mathrm{mg} / \mathrm{L}$ olan amonyak azotu miktarı sonbahar mevsiminde ise 0,0085 $\mathrm{mg} / \mathrm{L}$ 'ye düşmüştür. En düşük değer ise kış mevsiminde $0,00612 \mathrm{mg} / \mathrm{L}$ olarak bulunmuştur.

Amonyak azotu miktarlarına bakıldığında Yusufeli > Hopa $>$ Şehir $>$ Seyitler $>$ Borçka Acarlar $>$ Arhavi $>$ Şavşat sıralaması elde edilmiştir.

\section{Tartışma ve Sonuç}

Yapılan bu çalışmada, AÇÜ yerleşkelerinden (Şehir, Seyitler, Hopa, Arhavi, Borçka Acarlar, Yusufeli, Şavşat) alınmış olan şebeke sularının fiziksel ve kimyasal yönden İçme Suları Standartlarına uygunluğunu araştırmak ve halk sağlığı açısından potansiyel bir risk oluşturup oluşturmadığının belirlenmesi amaçlanmıștır. Su numuneleri ilkbahar, yaz, sonbahar ve kış olmak üzere dönemsel olarak alınmıştır. Alınan örneklerin bulanıklık, iletkenlik, $\mathrm{pH}$, ÇO, sıcaklık, toplam sertlik, klorür, $\mathrm{NO}_{3}-\mathrm{N}$ ve $\mathrm{NH}_{3}-\mathrm{N}$ tayinleri yapılmıştır.

Şebeke suları Artvin ilinin her ilçesinde yeraltı ve yerüstü suları gibi farklı kaynaklardan dağıtılmaktadır. Kaynak çeșitliliği ise ölçülen parametrelerin değerlerinde farklıllğa sebebiyet vermektedir.

Dünyada en çözücü sıvı olan "Yağmur Suyu" toprakta bulunan azotlu maddeleri kısmen çözer, böylece azotlu bileşikler suya geçmiş olur. $\mathrm{Bu}$ nedenle yer üstünden veya yeraltından alınan sularda azotlu bileşiklerin bulunması doğaldır. Tarımsal bölgelerdeki kuyularda da tehlikeli miktarlarda $\mathrm{NH}_{4}{ }^{+}$iyonuna rastlanabilmektedir. Azotlu suni gübreler yağmur suları ile yeraltına geçmekte ve kuyu sularının kalitelerini riskli duruma getirmektedirler. Doğal olarak toprakta bulunan bazı bakteriler amonyumun okside olmasını sağlarlar, böylece amonyum önce nitrit ve daha çok okside olduktan sonra nitrat şekline dönüșür. Oksijene doymamıș olan nitrit insan vücudu içine girdiğinde kanda bulunan oksijeni kısmen tüketerek insana, özellikle bebeklere zarar verir. $\mathrm{Bu}$ nedenle ülkemizde kullanılan içme suyu yönetmeliğinde nitrit miktarı $0,5 \mathrm{mg} / \mathrm{L}$ olarak sınırlandırılmıştır [24].

Yusufeli ilçesinde şebeke suları 3 farklı kaynaktan elde edilmektedir. Bu kaynaklar kuyu, sondaj ve keson kuyularıdır. İlçedeki ölçümlerde özellikle iletkenlik ve sertlik değerlerinin fazla olduğu görülmektedir. Bunun en büyük nedenlerinden biri suların kaynakları olarak gösterilebilir. Belediyeden alınan sözlü bilgiye göre şebeke hatlarının eski olması iletkenlik parametresinin yüksek olmasının etkenlerinden bir diğeridir. Türkiye'nin en büyük inşaat projelerinden olan Yusufeli barajı ve buna bağlı olarak ilçenin yeni yerine taşınacak olmasından dolayı şu an için şebeke hatların yenilenmesi de söz konusu değildir.

Artvin merkez ilçesinde bulunan ve Şehir Yerleşkesine gelen şebeke suları Çoruh Nehri'nde açlan 2 adet keson kuyudan içme suyu deposuna pompalanmakta ve orada klolarlandıktan sonra yerleşke ve çevresine verilmektedir. Bu alandaki hatlar 1976 yılında İller Bankası tarafından inşa edilmiş olup günümüze kadar herhangi bir yenileme yapılmamıştır. İletkenlik ve klordaki yüksek değerler yüksek ihtimalle bununla bağlantılıdır. Nitrat miktarındaki fazlalık nedeni ile Çoruh Nehri'nde ve yeraltı sularında kontaminasyon olabilir. Standartlara göre sınır değerleri ilkbahar aylarında aşıldığından dolayı bu parametrenin düzenli olarak izlenmesi ve esas kaynağının araştırılması gerekmektedir.

Merkez ilçe Seyitler Köyü sınırları içerisinde yer alan Seyitler Yerleşkesi'nin şebeke sularının dağıtımını Yedigözeler kooperatifi yapmaktadır. Söz konusu bu sular memba kaynaklıdır. Merkez yerleșkenin bulunduğu alana göre yoğun olarak yapılan tarım ve hayvancllık faaliyetleri özellikle ilkbahar aylarında nitratın yüksek çıkmasına neden olmaktadır.

Şavşat ilçesinin içme ve kullanma suları ilçeye $8 \mathrm{~km}$ mesafedeki Nazlıkara membasından karşılanmaktadır. Parametre karşılaştırmalarına göre fizikokimyasal özellikleri en iyi ş̧ebeke suyunun Şavşat ilçesine ait olduğu söylenebilir. 
Arhavi ilçesine gelen şebeke suları Lome su paket arıtma tesisinden sağlanmaktadır. Türkiye'nin en çok yağış alan yerlerinden biri olan Arhavi'de bulanıklığın özellikle sonbahar aylarında artması yağışların fazla olması ve paket arıtma tesis kapasitesinin yetersiz kalması gösterilebilir.

Hopa ilçesindeki şebeke suları, ilçe sınırlarında bulunan Balıklı Deresi'nin başlangıcındaki su toplama merkezinden sağlanmaktadır. Şebeke suları fizikokimyasal parametreler bakımından sınır değerleri aşmamaktadır.

Borçka'da ise Kameni bölgesinde bulunan içme suyu arıtma tesisinden ilçeye su verilmektedir. İlçede yapılan tarımsal ve hayvansal faaliyetler nedeniyle ilkbahar aylarında nitrat değeri yüksek bulunmuştur.

Nitrat parametresinin özellikle kış aylarında artışına neden olarak yağışlar sonucu toprağın yıkanmasıyla bünyesinde nitratlar birikebilmesi ve yeraltı sularına karışabilmesi olarak yorumlanabilir. Yaz mevsiminde yağışların nispeten az olması ile birlikte şebeke suyundaki nitrat miktarında azalmalar meydana gelebilmektedir.

Genel olarak ÇO değerinin en yüksek olduğu mevsim kış olarak görülmektedir. $\mathrm{Bu}$ duruma havaların soğuması ile su sıcaklığının düșmesi gösterilebilir.

Dünya standartları arasında sıcaklık için herhangi bir limit değer olmamasına rağmen; soğuk su, genellikle ılık sudan daha tatlıdır. Ayrıca sıcaklığı fazla olan sularda mikroorganizmaların büyüme hızında artış ve buna bağlı olarak; tat, koku, renk ve korozyon sorunları gözlenebilir.

Yerleşkelerde bazı personelin ve özellikle de öğrencilerin su ihtiyaçları için musluklardan akan suları kullandığı tespit edilmiştir. Bu durum musluk suları kalitesinin önemini arttırmaktadır. Nitrat haricinde elde edilen değerler TS 266 İçme Suyu Kalite Parametre Değerleri, AB, DSÖ ve İTASHY'de verilen limit değerleri içerisinde kaldığı tespit edilmiştir. Ancak suların farklı kaynaklardan gelmeleri ve mevsimsel farklılıklar nedenleriyle hem yerleşkelerdeki numuneler hem de aynı yerleşkelerde mevsimsel alınan numuneler arasında farklar mevcuttur. Çalışma alanındaki yerleşkelerde kullanılan şebeke sularının insan sağlı̆̆ için güvenli olup olmadığının tespiti adına yapılan bu analizlerin sıklaştırılması, izlenecek parametrelerin arttırılması ve ayrıca mikrobiyolojik etkinliklerinin de incelenmesi gerekmektedir. Böylelikle bu yerleşim merkezlerindeki suların özellikleri hakkında daha sağlıklı bir değerlendirme yapılabilir.

\section{Teşekkür}

$\mathrm{Bu}$ çalışma "Artvin Çoruh Üniversitesi yerleşkelerine gelen şebeke sularının bazı fiziksel ve kimyasal özelliklerinin araştırılması" isimli ve 2016.F40.02.04 kodlu Artvin Çoruh Üniversitesi Bilimsel Araştırma Projeleri Koordinatörlüğü (BAP) kapsamında gerçekleştirilmiştir.

\section{Kaynaklar}

[1] Mahmood Y, Kütük M, Ahmed T. 2014. Kerkük (Irak) ili içme suyunun kimyasal parametreleri açısından değerlendirilmesi. Caucasian Journal of Science, 1 (1), 62-72.

[2] Kırtorun E, Karaer F. 2018. Su Yönetimi ve Suyun Sürdürülebilirliği. Sürdürülebilir Mühendislik Uygulamaları ve Teknolojik Gelişmeler Dergisi, 1(2), 151-159.

[3] Tekeli T, Yücel Y, Tekeli Y. 2018. Hatay'da kullanılan kuyu sularının içme suyu kalite parametreleri bakımından incelenmesi ve kemometrik yöntemlerle karakterizasyonu. Karadeniz Fen Bilimleri Dergisi, 8(2), 70-83.

[4] Solak S, Kılıç MY, Solmaz SKA. 2019. Bursa ilinde sürdürülebilir kentsel su yönetimi. Uludağ Üniversitesi Mühendislik Fakültesi Dergi, 24(1), 111-124.

[5] Muluk ÇB, Kurt B, Turak A, Türker A., Çalışkan MA, Balkız Ö, Gümrükçü S, Sarıgül G, Zeydanlı U. 2013. Türkiye'de Suyun Durumu ve $\mathrm{Su}$ Yönetiminde Yeni Yaklaşımlar: Çevresel Perspektif. İş Dünyası ve Sürdürülebilir Kalkınma Derneği-Doğa Koruma Merkezi, http://www.dkm.org.tr/dosyalar/yayindosya_ rnf27jiq.pdf (15.04.2019)

[6] Demirel M. 2009. Su kaynakları yönetimindeki politika ve sorunlar: Denizli örneğinde bir değerlendirme, Y.L. Tezi, Pamukkale Üniversitesi Sosyal Bilimler Enstitüsü, Kamu Yönetimi Anabilim Dalı, Denizli.

[7] Yılmaz A. 2015. Küresel ısınmanın dünya su rezervleri üzerindeki etkileri. Kent Akademisi, 8(22), 63-72.

[8] Kılıç S. 2008. Küresel iklim değişikliği sürecinde su yönetimi". İstanbul Üniversitesi Siyasal Bilgiler Fakültesi Dergisi, 0(39), 161186.

[9] Birici N, Karakaya G, Şeker T, Küçükyılmaz M, Balcı M, Özbey N, Güneş M. 2017. Evaluation of Coruh River (Bayburt) water quality in accord with water pollution control regulation. International Journal of Pure and Applied Sciences, 3 (1), 54-64.

[10] Feitelson E. 2012. What is water? A normative perspective, Water Policy, 14, 52-64. 
[11] Akdağ R. 2015. Kentsel su sunumunda bir yönetim aracı olarak su talep tahmini. Niğde Üniversitesi İktisadi ve İdari Bilimler Fakültesi Dergisi, 8(3), 69-81.

[12] Dedekayoğulları H, Önal A. 2009. Çevre-İnsan Sağlığı İlişkisi Açısından Su ve Su Analizinin Önemi", İstanbul Tıp Fakültesi Dergisi, 72(2), 65-70.

[13] Anonim. 2019. The Use of Water Today. https://www.worldwatercouncil.org/fileadmi n/wwc/Library/WWVision/Chapter2.pdf [Erişim Tarihi: 10.03.2019].

[14] Süphandağ ŞA, Uyguner CS, Bekbölet M. 2007. İstanbul'da tüketilen ticari ve şebeke bazlı içme sularının kimyasal ve spektroskopik profilleri. İtüdergisi/e su kirlenmesi kontrolü, $17(2), 23-35$

[15] Şengörür B, Demirel A. 2002. Akgöl'de (Gölkent-Sakarya) ötrofikasyon ve su kalite sinıfinın belirlenmesi". Sakarya University Journal of Science, 6 (3), 1-8.

[16] Anonim. 1997. TS-266. ICS 13.060.20. Sularİçme ve Kullanma Suları. TSE, Türk Standardı, 35s., Ankara.

[17] Anonim. 1988. İçme Suları Rehber Kitabı. T.C. Sağlık Bakanlığı Yayını, 225s. Ankara.
[18] Anonim. 2006. Guidelines for Drinking-water Quality. Vol.I. World Health Organization. 595 s. Switzerland

[19] itashy, 2005. İnsani Tüketim Amaçlı Sular Hakkında Yönetmelik, Resmî Gazete Tarihi: 17.02.2005 Resmî Gazete Sayısı: 25730

[20] Yüksek T, Ölmez Z. 2002. Artvin yöresinin iklim, toprak yapısı, orman alanları, ağaç serveti ve ormancılık çalışmalarıyla ilgili genel bir değerlendirme. Kafkas Üniversitesi Artvin Orman Fakültesi Dergisi,1, 50-62.

[21] Eminağaoğlu, Ö., Beğen, H.A., Aksu, G. 2015. Artvin'in Genel Tanımı. ss 1-26. Eminağaoğlu, Ö., ed. 2015. Artvin'in Doğal Bitkileri, Promat Basım Yayın, İstanbul, 456s.

[22] Anonim. 2019. What is the factor to convert from NO3-N and NO3? Document ID TE387. https://support.hach.com/ [Erişim Tarihi: 25.04.2019].

[23] Türkiye İstatistik Kurumu. 2019. Adrese Dayalı Nüfus Kaylt Sistemi. http://www.tuik.gov.tr [Erişim Tarihi:25.04.2019].

[24] Burkut, E. 2018. Suda Amonyum, Nitrit ve Nitrat. Su ve Çevre Teknolojileri, 13(120), 20 22. 